\title{
PENGARUH FUNGISIDA PROPINEB TERHADAP Colletotrichum spp. PENYEBAB PENYAKIT ANTRAKNOSA PADA CABAI MERAH
}

\author{
Yunita Fitri Astuti, Tri Maryono*, Joko Prasetyo \& Suskandini Ratih \\ Jurusan Agroteknologi, Fakultas Pertanian Universitas Lampung \\ Jl.Prof. Soemantri Brodjonegoro, No.1, Bandar Lampung 35145 \\ Email: uti.yunita@yahoo.com \\ *Korespondensi: Email: trimaryono80@gmail.com
}

\begin{abstract}
ABSTRAK
Produktivitas cabai di Indonesia umumnya masih rendah yaitu 5,5 ton ha ${ }^{-1}$, sedangkan potensi hasil yang dapat dicapai ialah 17-21 ton ha-1. Salah satu faktor penyebabnya adalah penyakit antraknosa. Penyakit antraknosa disebabkan oleh jamur Colletotrichum spp. Penyakit antraknosa umumnya dikendalikan dengan aplikasi fungisida sintetik berbahan aktif propineb. Tujuan dari penelitian ini adalah untuk mengetahui pengaruh fungisida berbahan aktif propineb terhadap Colletotrichum spp. penyebab penyakit antraknosa pada cabai merah. Penelitian dilaksanakan di Laboratorium Penyakit Tumbuhan, Jurusan Agroteknologi, Fakultas Pertanian, Universitas Lampung dari Nopember 2012 sampai Maret 2013. Penelitian disusun menggunakan Rancangan Acak Lengkap (RAL), dengan lima perlakuan tingkat konsentrasi yaitu: kontrol/tanpa fungisida (P0), 700 ppm (P1), 1400 ppm (P2), 2100 ppm (P3) dan 2800 ppm (P4) dengan tiga ulangan. Data yang diperoleh dianalisis dengan sidik ragam dan perbedaan nilai tengah antar perlakuan di uji dengan uji Beda Nyata Terkecil $(\mathrm{BNT})$ pada $\alpha=0,05$. Hasil penelitian menunjukkan bahwa persentase penghambatan pertumbuhan diameter koloni jamur $C$. capsici dan $C$. gloesporioides yang diperoleh dari Palas, Natar, Sragi, Ketapang, dan Tanjung Bintang hingga mencapai 100\% pada semua rentang konsentrasi yang diujikan. Hasil ini menunjukkan bahwa jamur C. capsici dan C. gloesporioides masih sangat sensitif terhadap fungisida berbahan aktif propineb.
\end{abstract}

Kata kunci : antraknosa, cabai, Colletotrichum spp., propineb, sensitivitas.

\section{PENDAHULUAN}

Cabai merah (Capsicum annuum L.) merupakan komoditas sayuran yang bernilai ekonomi tinggi. Produktivitas cabai di Indonesia umumnya masih rendah yaitu 5,5 ton/ha. Menurut Bahar dan Nugrahaeni (2008), potensi hasil yang dapat dicapai ialah 17-21 ton ha ${ }^{-1}$. Salah satu faktor penyebab rendahnya produktivitas cabai di Indonesia adalah gangguan hama dan penyakit (Semangun, 2000). Penyakit antraknosa merupakan salah satu penyakit utama yang menyebabkan rendahnya produktivitas cabai di Indonesia (Syukur et al., 2009). Penyakit antraknosa pada cabai disebabkan oleh jamur Colletotrichum, diantaranya yaitu $C$. gloeosporioides, C. acutatum, C. dematium, $C$. capsici dan $C$. coccodes.

Jamur $C$. capsici dan $C$. gloeosporioides merupakan spesies yang menyebabkan kerusakan pada buah dan kehilangan hasil paling besar. Kehilangan hasil yang diakibatkan oleh penyakit ini dapat lebih dari 50\% (Kusnadi et al., 2009). Upaya pengendalian penyakit antraknosa yang dilakukan sampai saat ini adalah dengan aplikasi fungisida sintetik berbahan aktif propineb. Adiyoga dan Soetiarso (1999) melaporkan bahwa 80\% petani cabai menggunakan fungisida untuk mengendalikan penyakit tanaman. Salah satu dampak dari penggunaan fungisida adalah terjadinya penurunan sensitivitas (terjadi resistensi) terhadap jamur. Oleh karena itu, perlu dilakukan pengujian pengaruh fungisida berbahan aktif propineb terhadap Colletotrichum spp.

\section{BAHAN DAN METODE}

Penelitian dilaksanakan di Laboratorium Penyakit Tumbuhan, Jurusan Agroteknologi, Fakultas Pertanian, Universitas Lampung. Penelitian ini dilakukan dari Nopember 2012 sampai Maret 2013. Penelitian secara in vitro menggunakan Rancangan Acak Lengkap (RAL). Perlakuan terdiri dari lima taraf konsentrasi fungisida berbahan aktif propineb, yaitu kontrol/tanpa fungisida (P0), 1/2 konsentrasi anjuran (700 ppm)(P1), konsentrasi anjuran (1400 ppm)(P2), 1,5x konsentrasi anjuran (2100 ppm) (P3) dan 2x konsentrasi anjuran $(2800 \mathrm{ppm})(\mathrm{P} 4)$. Masing - masing perlakuan diulang sebanyak tiga kali. Data yang diperoleh dianalisis dengan sidik ragam dan perbandingan nilai tengah antar perlakuan di uji dengan uji Beda Nyata Terkecil (BNT) pada $\alpha=0,05$. 
Penelitian ini didahului dengan survei penggunaan jenis fungisida oleh petani cabai. Survei dilakukan di lima kecamatan di Kabupaten Lampung Selatan, Kecamatan yaitu Natar, Tanjung Bintang, Palas, Sragi, dan Ketapang. Lokasi tersebut dipilih berdasarkan lahan pertanaman cabai yang terluas dan mudah dijangkau. Kegiatan yang dilakukan mencari informasi tentang cara budidaya dan jenis fungisida yang digunakan petani untuk mengendalikan penyakit cabai terutama penyakit antraknosa serta mengambil beberapa buah cabai yang bergejala antraknosa untuk diidentifikasi dan di lakukan pengujian lebih lanjut di Laboratorium Penyakit Tumbuhan, Fakultas Pertanian, Universitas Lampung.

Jamur Colletotrichum spp. diisolasi dari buah cabai merah besar yang bergejala antraknosa yang diambil dari pertanaman cabai di lima kecamatan di Kabupaten Lampung Selatan. Kulit buah cabai yang bergejala antraknosa tersebut kemudiandi potong kecilkecil bagian antara yang sehat dengan yang sakit, kemudian potongan-potongan kulit buah cabai tersebut direndam dalam larutan klorok $1 \%$ selama 1 menit, lalu dibilas dengan air steril. Selanjutnya potongan-potongan kulit buah cabai tersebut ditanamkan pada media PDA. Koloni jamur yang tumbuh kemudian dimurnikan dan diidentifikasi. Identifikasi dilakukan berdasarkan karakter morfologi jamur menggunakan kunci identifikasi Barnet \& Hunter (2001) serta dibandingkan dengan literatur pendukung seperti Than et al. (2008).

Pengujian fungisida berbahan aktif propineb terhadap Colletotrichum spp. dilakukan menggunakan metode mycelial growth assays dengan teknik makanan beracun. Cuplikan miselia jamur Colletotrichum spp. dari biakan berumur tujuh hari diambil menggunakan cork borer berdiameter $5 \mathrm{~mm}$. Cuplikan miselia tersebut kemudian diletakkan secara terbalik (miselia jamur berada dibawah) pada media PDA yang telah dicampur dengan fungisida propineb dalam cawan petri. Pencampuran fungisida dilakukan setelah media diautoklaf. Cawan petri yang telah berisi cuplikan miselia jamur Colletotrichum spp. kemudian diinkubasi pada suhu ruang dengan pencahayaan alami selama tujuh hari.
Peubah yang diamati dalam pengujian ini adalah diameter koloni jamur Colletotrichum spp. Pengukuran diameter koloni jamur Colletotrichum spp. dilakukan setiap hari selama tujuh hari. Dari data diameter koloni jamur Colletotrichum spp., kemudian dihitung persentase penghambatan fungisida terhadap pertumbuhan koloni jamur Colletotrichum spp. Persentase penghambatan pertumbuhan koloni jamur Colletotrichum spp. oleh fungisida berbahan aktif propineb, dihitung dengan rumus sebagai berikut (Kumar et al., 2007):

$$
\mathrm{I}=\frac{\mathrm{C}-\mathrm{T}}{\mathrm{C}} \times 100
$$

dengan $\mathrm{I}=$ penghambatan $(\%), \mathrm{C}=$ diameter koloni jamur pada kontrol $(\mathrm{mm})$, dan $\mathrm{T}=$ diameter koloni pada perlakuan (mm).

Berdasarkan nilai persentase penghambatan fungisida terhadap pertumbuhan jamur Colletotrichum, kemudian ditentukan tingkat sensitifitas jamur Colletotrichum terhadap konsentrasi fungisida uji. Tingkat sensitifitas jamur Colletotrichum terhadap konsentrasi fungisida uji didasarkan pada kategori berikut : sangat sensitif (SS) apabila terhambat $>90 \%$, sensitif (S) apabila terhambat $>75-90 \%$, moderate resisten (MR) apabila terhambat $>60-75 \%$, resisten (R) apabila terhambat $>40-60 \%$, dan sangat resisten (SR) apabila pertumbuhan jamur terhambat $<40 \%$ (Kumar et al., 2007).

\section{HASIL DAN PEMBAHASAN}

Hasil survei di lima kecamatan di Kabupaten Lampung Selatan mununjukkan bahwa petani cabai menggunakan fungisida berbahan aktif propineb untuk mengendalikan penyebab penyakit antraknosa. Pada umumnya petani menggunakan fungisida secara intensif yaitu antara 4-5 hari sekali, khusus petani cabai di Kecamatan Tanjung Bintang, menggunakan fungisida secara tidak intensif (tidak terjadwal) (Tabel 1).

Tabel 1. Jenis dan intensitas pemakaian fungisida pada petani cabai di lima kecamatan di Lampung Selatan

\begin{tabular}{lccc}
\hline \multicolumn{1}{c}{ Kecamatan } & Luas lahan $\left(\mathrm{m}^{2}\right)$ & Fungisida yang dipakai & Intensitas pemakaian fungisida \\
\hline Palas & 5000 & Karbendazim & Intensif (4-5 hari sekali) \\
Natar & 2000 & Karbendazim & Intensif (4-5 hari sekali) \\
Sragi & 5000 & Propineb & Intensif (4-5 hari sekali) \\
Ketapang & 5000 & Propineb & Intensif (4-5 hari sekali) \\
Tanjung Bintang & 1200 & Propineb & Tidak intensif (tidak terjadwal) \\
\hline
\end{tabular}


Hasil isolasi jamur dari buah cabai dengan gejala antraknosa menunjukkan adanya dua spesies jamur Colletotrichum yang berbeda yaitu C. capsici dan $C$. gloesporioides. C. capsici mempunyai warna koloni abu-abu kehitaman, aservulus tersebar dibawah kutikula atau pada permukaan buah, banyak seta, bersekat dan mempunyai konidia yang ujung-ujungnya tumpul atau bengkok seperti bulan sabit. C. gloesporioides mempunyai aservulus dalam sel-sel epidermal, warna koloni putih keabu-abuan dengan konidia berbentuk bulat panjang (seperti kapsul) (Gambar 1).

Berdasarkan hasil pengujian diketahui bahwa pada semua konsentrasi yang diujikan, propineb efektif menghambat pertumbuhan jamur $C$. gloesporioides dan C. capsici (Gambar 2, Tabel 2). Hal ini dapat dilihat dari nilai persentase penghambatan pertumbuhan koloni jamur Colletotrichum spp. yang mencapai $100 \%$ pada hari ke tujuh setelah aplikasi fungisida berbahan aktif propineb (Tabel 3).

Dari hasil ini terlihat bahwa $C$. capsici dan $C$. gloesporioides yang diuji masih sangat sensitif terhadap bahan aktif propineb. Berdasarkan kriteria sensivitas jamur trhadap fungisida yang dikemukakan oleh Kumar et al. (2007), suatu jamur dikatakan sensitif apabila pertumbuhannya terhambat $>90 \%$ bila ditumbuhkan pada media yang mengandung bahan aktif suatu fungisida. Pada penelitian ini, baik C. capsici dan $C$. gloesporioides terhambat $100 \%$ (tidak mampu tumbuh) pada media tumbuh yang diberi propineb. Bahkan pada takaran setengan dosis dari dosis anjuran pada label, $C$. capsici dan C. gloesporioides juga tidak mampu tumbuh (Tabel 4).

Propineb merupakan jenis fungisida yang berkerja secara kontak (racun kontak). Pada umumnya, peluang dari fungisida jenis ini untuk terjadi resistensi pada targetnya lebih kecil dibandingkan dengan fungisida sistemik. Hal ini dikarenakan, fungisida kontak tidak spesifik target seperti fungisida sistemik.

Pada penelitian ini ditemukan bahwa $C$. capsici dan $C$. gloesporioides juga sangat sensitif terhadap propineb pada dosis setengah dari dosis anjuran pada label. Meskipun hal ini baru sekali ini ditemukan, mungkin dalam aplikasinya, petani dapat menggunakan dosis setengan dari dosis anjuran untuk mengendalikan penyakit antraknosa pada cabainya.
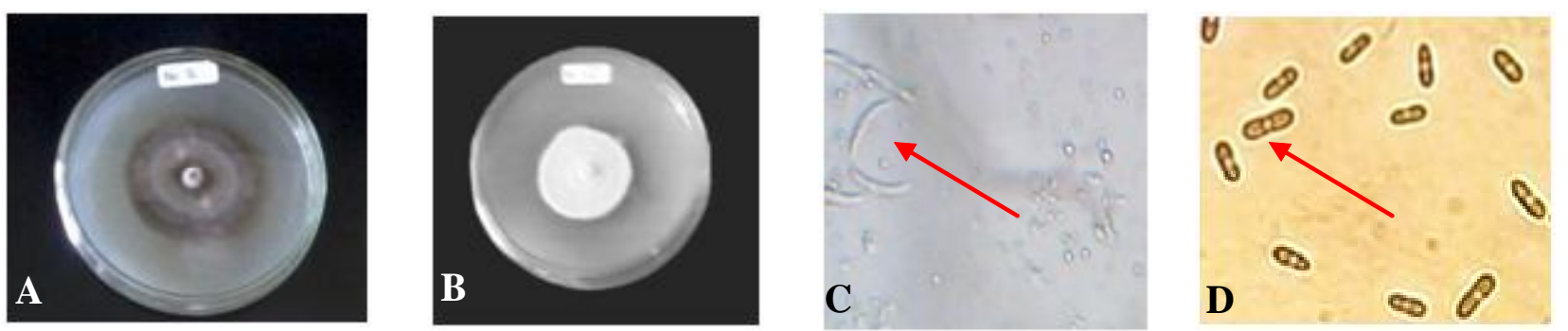

Gambar 1. Koloni dan konidia Colletotrichum spp. hasil isolasi dai buah bergejala antraknosa. A = Koloni $C$. capsici, $\mathrm{B}=$ koloni $C$. gloesporioides, $\mathrm{C} .=$ konidia $C$. capsici, $\mathrm{D}=$ konidia $C$. gloesporioides.
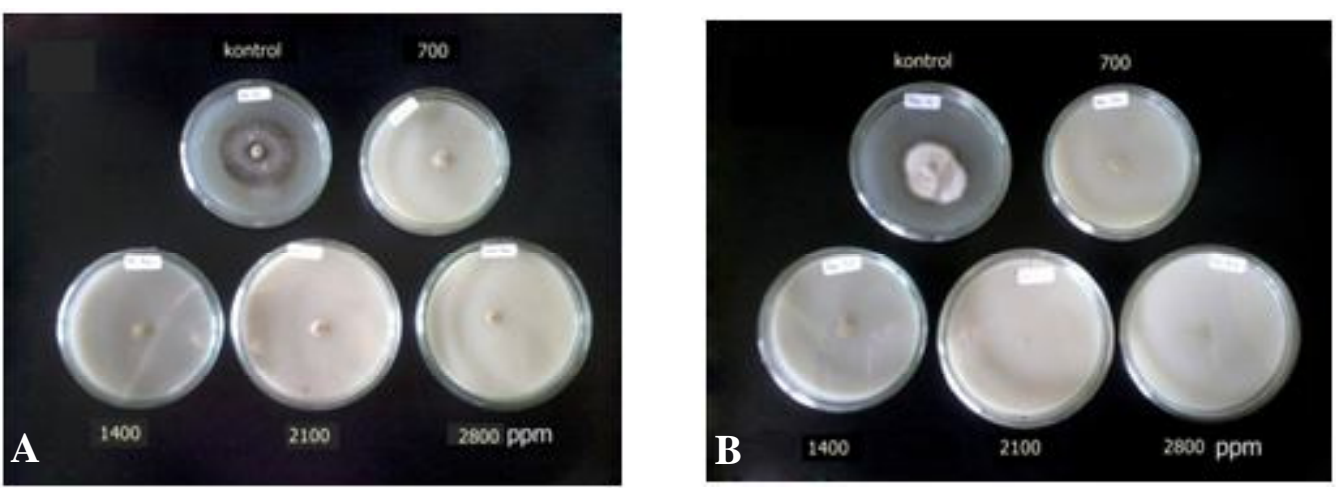

Gambar 2. Diameter koloni jamur Colletotrichum spp pada media dengan penambahan propineb. $\mathrm{A}=$ C. capsici dan $\mathrm{B}=$ C. gloespoioides . 
Tabel 2. Diameter koloni jamur Colletotrichum spp. pada media PDA yang telah dicampur dengan fungisida propineb pada tujuh hari setelah aplikasi

\begin{tabular}{llccccc}
\hline & & \multicolumn{5}{c}{ Diameter koloni (mm) } \\
\cline { 3 - 6 } Spesies jamur & $\begin{array}{l}\text { Daerah asal } \\
\text { isolat }\end{array}$ & \multicolumn{5}{c}{ Konsentrasi fungisida propineb } \\
\cline { 2 - 6 } & & $0 \mathrm{ppm}$ & $700 \mathrm{ppm}$ & $1400 \mathrm{ppm}$ & $2100 \mathrm{ppm}$ & $2800 \mathrm{ppm}$ \\
\hline C. capsici & Palas & $41 \mathrm{a}$ & $0 \mathrm{~b}$ & $0 \mathrm{~b}$ & $0 \mathrm{~b}$ & $0 \mathrm{~b}$ \\
C. gloesporioides & Natar & $44,2 \mathrm{a}$ & $0 \mathrm{~b}$ & $0 \mathrm{~b}$ & $0 \mathrm{~b}$ & $0 \mathrm{~b}$ \\
& Tj. Bintang & $30,2 \mathrm{a}$ & $0 \mathrm{~b}$ & $0 \mathrm{~b}$ & $0 \mathrm{~b}$ & $0 \mathrm{~b}$ \\
& Ketapang & $32,5 \mathrm{a}$ & $0 \mathrm{~b}$ & $0 \mathrm{~b}$ & $0 \mathrm{~b}$ & $0 \mathrm{~b}$ \\
& Sragi & $28,7 \mathrm{a}$ & $0 \mathrm{~b}$ & $0 \mathrm{~b}$ & $0 \mathrm{~b}$ & $0 \mathrm{~b}$ \\
\hline
\end{tabular}

Keterangan: Huruf yang sama di belakang angka secara mendatar menyatakan tidak berbeda nyata pada uji BNT pada $\alpha=0,05$.

Tabel 3. Diameter koloni jamur Colletotrichum spp. pada media PDA yang telah dicampur dengan fungisida propineb pada tujuh hari setelah aplikasi

\begin{tabular}{llccccc}
\hline & & \multicolumn{5}{c}{ Diameter koloni (mm) } \\
\cline { 2 - 6 } Spesies jamur & $\begin{array}{l}\text { Daerah asal } \\
\text { isolat }\end{array}$ & \multicolumn{5}{c}{ Konsentrasi fungisida propineb } \\
\cline { 2 - 7 } & & $0 \mathrm{ppm}$ & $700 \mathrm{ppm}$ & $1400 \mathrm{ppm}$ & $2100 \mathrm{ppm}$ & $2800 \mathrm{ppm}$ \\
\hline C. capsici & Palas & $41 \mathrm{a}$ & $0 \mathrm{~b}$ & $0 \mathrm{~b}$ & $0 \mathrm{~b}$ & $0 \mathrm{~b}$ \\
C. gloesporioides & Natar & $44,2 \mathrm{a}$ & $0 \mathrm{~b}$ & $0 \mathrm{~b}$ & $0 \mathrm{~b}$ & $0 \mathrm{~b}$ \\
& Tj. Bintang & $30,2 \mathrm{a}$ & $0 \mathrm{~b}$ & $0 \mathrm{~b}$ & $0 \mathrm{~b}$ & $0 \mathrm{~b}$ \\
& Ketapang & $32,5 \mathrm{a}$ & $0 \mathrm{~b}$ & $0 \mathrm{~b}$ & $0 \mathrm{~b}$ & $0 \mathrm{~b}$ \\
& Sragi & $28,7 \mathrm{a}$ & $0 \mathrm{~b}$ & $0 \mathrm{~b}$ & $0 \mathrm{~b}$ & $0 \mathrm{~b}$ \\
\hline
\end{tabular}

Keterangan: Huruf yang sama di belakang angka secara mendatar menyatakan tidak berbeda nyata pada uji BNT pada $\alpha=0,05$.

Tabel 4. Kategori sensitifitas jamur Colletotrichum spp. terhadap fungisida propineb

\begin{tabular}{|c|c|c|c|c|c|}
\hline \multirow{3}{*}{ Spesies jamur } & \multirow{3}{*}{$\begin{array}{c}\text { Daerah asal } \\
\text { isolat }\end{array}$} & \multicolumn{4}{|c|}{ Persentase penghambatan jamur Colletotrichum } \\
\hline & & \multicolumn{4}{|c|}{ Konsentrasi fungisida propineb } \\
\hline & & $700 \mathrm{ppm}$ & $1400 \mathrm{ppm}$ & $2100 \mathrm{ppm}$ & $2800 \mathrm{ppm}$ \\
\hline C. capsici & Palas & $100 \%(\mathrm{SS})$ & $100 \%(\mathrm{SS})$ & $100 \%(\mathrm{SS})$ & $100 \%(\mathrm{SS})$ \\
\hline \multirow{4}{*}{ C. gloesporioides } & Natar & $100 \%(\mathrm{SS})$ & $100 \%(\mathrm{SS})$ & $100 \%(\mathrm{SS})$ & $100 \%(\mathrm{SS})$ \\
\hline & Tj. Bintang & $100 \%(\mathrm{SS})$ & $100 \%(\mathrm{SS})$ & $100 \%(\mathrm{SS})$ & $100 \%(\mathrm{SS})$ \\
\hline & Ketapang & $100 \%(\mathrm{SS})$ & $100 \%(\mathrm{SS})$ & $100 \%(\mathrm{SS})$ & $100 \%(\mathrm{SS})$ \\
\hline & Sragi & $100 \%(\mathrm{SS})$ & $100 \%(\mathrm{SS})$ & $100 \%$ (SS) & $100 \%(\mathrm{SS})$ \\
\hline
\end{tabular}

Keterangan: SS = Sangat sensitif. 


\section{KESIMPULAN}

Berdasarkan hasil penelitian disimpulkan bahwa jamur C. capsici dan C. gloesporioides pada cabai yang berasal dari Palas, Natar, Tanjung Bintang, Ketapang, dan Sragi masih sangat sensitif terhadap fungisida propineb.

\section{DAFTAR PUSTAKA}

Adiyoga, W dan T.A. Soetiarso. 1999. Strategi Petani Dalam Mengelola Risiko Pada Usaha Tani Cabai. Jurnal Hortikultura 8(4): 1299-1311.

Bahar, Y.H. dan W. Nugraheni. 2008. Hasil Survei Produktivitas Hortikultura. Diunduh 15 Oktober 2012, 〈http://www.hortikultura.deptan.go.id>

Barnet, H.L. and B.B. Hunter. 2001. Ilustrated Genera of Imperfect Fungi. Ed ke- 4. New York. Macmilan.

Kumar, A.S., N.P.E. Reddy, K.H. Reddy, and M.C. Devi. 2007. Evaluation of fungisidal resistance among Colletotrichum gloeosporioides isolates causing mango anthracnose in Agri Export Zone of Andhra Pradesh, India. Plant Pathol. Bull. 16: $157-160$.
Kusnadi, R., A. Sutarya, dan Munandar. 2009. Pengaruh Biofungisida Bacillus suptilis dan Mulsa Terhadap Serangan Penyakit Antraknosa Pada Cabai Merah (Capsicum annum L.). J. Biosainstifika 1(2):124-138.

Semangun, H. 2000. Penyakit-Penyakit Tanaman Hortikultura di Indonesia. Universitas Gajah Mada Press. Yogyakarta.

Syukur, M.S., Sujiprihati. J. Koswara, dan Widodo. 2009. Ketahanan Antraknosa yang Disebabkan oleh Colletotrichum acutatum pada Beberapa Genotipe Cabai (Capsicum annuum L.) dan Korelasinya dengan Kandungan Kapsaicin dan Peroksidase. Jurnal Agronomi Indonesia 37 (3): 233-239.

Than P.P., R. Jeewon, K.D. Hyde, S. Pongsupasamit, O. Mongkolporn, and P.W.J. Taylor. 2008. Characterization and pathogenicity of Colletotrichum species associated with anthracnose on chilli (Capsicum spp.) in Thailand. Plant Pathology 57:62-572. 